\title{
ASSESSMENT OF EVAPOTRANSPIRATION LOSS OF WATER FROM RICE AND WHEAT PLANTS GROWN IN SAND AND SANDY SOIL IN EARTHEN POTS UNDER FLOOD IRRIGATION
}

\author{
MD. KHALILUR RAHMAN* \\ Department of Soil, Water and Environment, University of Dhaka, Dhaka-1000, Bangladesh
}

Key words: Evapotranspiration loss, Flood irrigation system, Sand, Sandy soil

Evaporation from the soil surface is essentially the evaporation of water surrounding the soil particles as thin films and filling the pore spaces between them. Transpiration involves continuous movement of water from the roots, through the stem and lost through the leaves to the atmosphere. Land drainage reduces excessive wetness, encouraging gaseous exchange between the atmosphere and the soil thereby modifying the physical properties of soil conducive to root growth. Evapotranspiration includes both transpiration from plants and evaporation from the soil surface. It is controlled by (a) climatic conditions, (b) plant cover in relation to soil surface, (c) efficiency of water use by different plants and management practices and (d) length and season of the plant growing period ${ }^{(1)}$. Evapotranspiration value may vary according to differences in climatic conditions (2). Soil water availability is a factor of increasing concern for most crop production under both rainfed and irrigated systems. Efficient field tools and sophisticated instrumentation techniques are needed to monitor soil moisture and crop demand for water under different irrigation systems. Adaptive management practices are needed to promote optimal soil physical, chemical and biological properties, stimulate deep rooting within the soil profile, and lessen the impact of reduced water availability $^{(3)}$. Water use efficiency (WUE) has several important implications related to agricultural sustainability, soil and water conservation ${ }^{(4)}$. Water is becoming a scarce input particularly in sand - dominated areas owing to climate change, increased water demand for irrigation and excessive growth of population. Besides water unavailability throughout the crop growing period is a threat for agricultural productivity. The quantity of gravitational water in a soil is related to several conditions, including the amount of precipitation, evaporation rates, how easily the water can move through the soil and the space available for water storage. Irrigation accuracy depends mainly on correct estimates of crop evapotranspiration, available soil water and soil types.

In Lalmonirhat, dried up Teesta river in winter affects farming, fishing and communication. In Bogra, at Sariakandi and Dhunat upazilas farmers grow tomatoes in

*Author for correspondence: <khali193@du.ac.bd>. 
Jamuna river char lands(5). A good number of landless farmers of the different river basin areas of Bangladesh grow vegetable crops like pumpkin and squash(6) abundantly specially in winter on sand-dominated land to eradicate poverty and to meet the growing demand of the country. Farmers using organic manures and NPK fertilizers and supply irrigation water only. Farmers are getting training and financial help from NGOs. The Char lands as well as riverine islands are areas of new land formed through the continuous process of erosion and deposition in the major rivers and coastal areas. Char lands of Bangladesh can be divided into five sub-areas such as the Jamuna, the Ganges, the Padma, the upper Meghna and the lower Meghnariver. The old Brahmaputra and Teesta also constitute some char land areas. But irrigation is a major problem due to high rate of leaching loss of this land. The aim of the present experiment was to assess the evapotranspiration loss of water from rice and wheat plants grown in sand and sandy soil in square earthen pots having special openings at the bottom to simulate an ideal drainage condition under flood irrigation system.

The experiment was carried out in the Department of Soil, Water and Environment, University of Dhaka. Pots $(29.25 \mathrm{~cm} \times 29.25 \mathrm{~cm} \times 21 \mathrm{~cm})$ were arranged in a complete randomized block design. Each pot had a capacity for $12.8 \mathrm{~kg}$ of sand or soil. Sand and soil had a moisture at field capacity of 15.35 and $22.15 \%$, respectively. The soil being sandy loam in texture and had a pH of 7.2, organic carbon $0.62 \%$, available NPK were 85 , 4 and $120 \mathrm{mg} / \mathrm{kg}$, and total NPK were $0.08,0.03$ and $0.72 \%$, respectively. Nitrogen, P and $\mathrm{K}$ at the rates of 111, 84 and $84 \mathrm{~kg}$ per hectare were added to sand and sandy soil in the form of urea, TSP and MoP, respectively.

Six seedlings of rice of three weeks old were transplanted and six seeds of wheat were sown in sand and sandy soil media per pot. Seeds of rice and wheat were collected from Bangladesh Rice Research Institute (BRRI) and Bangladesh Agricultural Research Institute (BARI) Gazipur, respectively. Each morning, water was added at the rate of 2452 and $3316 \mathrm{ml}(>100 \%$ FC irrigation) per pot to sand and soil, respectively. Evapotranspiration loss was measured at 06:30, 08:30, 10:30, 12:30,14:30, 16:30 and 18:30 hours of the day at flowering stage under sun habitat by weighing the pots at regular intervals on a large scale top balance. Results shown are the mean of three replicates (Table 1). Loss of water through evapotranspiration for rice at $08: 30 \mathrm{hr}$ was 19.5 and $22 \mathrm{~g}$ and progressively increased up to $14: 30 \mathrm{hrs}$ and the values were 42.5 and $45 \mathrm{~g} / \mathrm{h}$, respectively. The total loss of water at daylight hours was 199.5 and $214.5 \mathrm{~g}$ in sand and sandy soil, respectively. For wheat plants, the evapotranspiration loss of water at 08:30 hour was 20 and $17.5 \mathrm{~g} / \mathrm{h}$ and progressively increased up to 14:30 hour and the values were 43 and $41 \mathrm{~g} / \mathrm{h}$ in sand and sandy soil, respectively. The total loss of water was 201 and 188 in sand and sandy soil, respectively (Table 1). Evapotranspiration loss of water increased from morning till noon and then decreased towards evening in both the media for both crops. The highest plateau of evapotranspiration loss was observed at 14:30 
hour. Evapotranspiration increased gradually due to increasing temperature which probably brought out the changes in the physiological characteristics for both crops and accelerated the rate of evaporation from land surface. Loss of water for rice was higher in sandy soil than in sand and it was reverse in case of wheat. The results did not vary significantly ( $\mathrm{p}=0.05)$. Growth and leaf area were also found higher for rice in sandy soil. Warm air temperatures increase the potential for evaporation and therefore increase rates of transpiration.

Table 1. Diurnal changes in evapotranspiration loss of water from rice and wheat plants grown in sand and sandy soil in earthen square pots having special openings at the bottom to simulate an ideal drainage condition under flood irrigation system.

\begin{tabular}{|c|c|c|c|c|c|c|c|c|}
\hline \multirow{2}{*}{$\begin{array}{l}\text { Treatment } \\
\text { Hours }\end{array}$} & \multicolumn{8}{|c|}{ Rate of evapotranspiration (g/hour) at day time } \\
\hline & 06:30 & $08: 30$ & 10:30 & 12:30 & 14:30 & $16: 30$ & 18:30 & $\begin{array}{l}\text { Total } \\
\text { loss }(\mathrm{g})\end{array}$ \\
\hline \multicolumn{9}{|c|}{ Rice } \\
\hline $\begin{array}{l}\text { Sand (loss of } \\
\text { water, } g / h)\end{array}$ & - & $\begin{array}{l}19.5 \\
\pm 2.56\end{array}$ & $\begin{array}{l}30.5 \\
+2.88\end{array}$ & $\begin{array}{l}38.0 \\
\pm 3.16\end{array}$ & $\begin{array}{l}42.5 \\
\pm 3.54\end{array}$ & $\begin{array}{l}37.5 \\
\pm 3.13\end{array}$ & $\begin{array}{l}31.5 \\
\pm 2.72\end{array}$ & 199.5 \\
\hline Sandy soil & - & $\begin{array}{l}22.0 \\
\pm 2.35\end{array}$ & $\begin{array}{l}32.5 \\
+2.59\end{array}$ & $\begin{array}{l}41.0 \\
+2.86\end{array}$ & $\begin{array}{l}45.0 \\
\pm 3.15\end{array}$ & $\begin{array}{l}40.5 \\
\pm 3.03\end{array}$ & $\begin{array}{l}33.5 \\
+2.67\end{array}$ & 214.5 \\
\hline \multicolumn{9}{|c|}{ Wheat } \\
\hline $\begin{array}{l}\text { Sand (loss of } \\
\text { water, } g / h)\end{array}$ & - & $\begin{array}{l}20.0 \\
+2.15\end{array}$ & $\begin{array}{l}30.0 \\
+2.28\end{array}$ & $\begin{array}{l}39.0 \\
+2.61\end{array}$ & $\begin{array}{l}43.0 \\
+2.66\end{array}$ & $\begin{array}{l}38.0 \\
+2.31\end{array}$ & $\begin{array}{l}31.0 \\
+2.16\end{array}$ & 201.0 \\
\hline Sandy soil & - & $\begin{array}{l}17.5 \\
\pm 1.94\end{array}$ & $\begin{array}{l}28.0 \\
\pm 2.10\end{array}$ & $\begin{array}{l}36.0 \\
\pm 2.32\end{array}$ & $\begin{array}{l}41.0 \\
+2.75\end{array}$ & $\begin{array}{l}35.5 \\
\pm 2.21\end{array}$ & $\begin{array}{l}30.0 \\
\pm 2.14\end{array}$ & 188.0 \\
\hline
\end{tabular}

$\pm=$ Standard deviation.

Evapotranspiration was higher in wheat plants grown in sand (Table 1). The results showed no significant $(\mathrm{p}=0.05)$ variation. Growth and leaf area were better in sand for wheat plants. Leaf area is an important variable for most eco-physiological studies in terrestrial ecosystems for elucidating competition among different plant species concerning irrigation response, evapotranspiration, plant growth and yield potential. The rate of growth of plant cells and the efficiency of their physiological processes are highest when the cells are at maximum turgor. Plant roots grow in an incredibly complex soil environment. Healthy soils sustain plants, animals and humans and function as a living ecosystem maintaining a diverse community of soil organisms that not only improve crop production, but also promote the quality of our air and water environments (7). Nakamura et al. ${ }^{(8)}$ conducted an experiment for three years in a sandy loam soil to investigate the effect of irrigation depths on the utilization of stored subsoil water by 
cabbage (Brassica oleracea L.) and maize (Zea mays L.). The results indicated that relatively dry conditions were necessary and drip irrigation (DI) was more efficient than subsurface drip irrigation (SDI) for subsoil water utilization under subtropical conditions at Ishigaki Island, JIRCAS Okinawa Subtropical Station, Japan.

The evapotranspiration loss values of the present experiment revealed that the degree of turgidity of plants and evaporation from land surface was affected by the application of excess water and less utilization of nutrients in water saturated conditions $(>100 \%$ FC irrigation) under flood irrigation system. Flood irrigation may not be useful in sand- dominated charlands because huge quantity of water and nutrients would be lost, perhaps surface and subsurface drip irrigation will be more efficient one.

\section{References}

1. Brady NC and Weil RC 2012.The Nature and Properties of Soils. 14 $4^{\text {th }}$ edition revised, Indian edition published by Dorling Kindersley India Pvt. Ltd. pp. 975.

2. Tan KH 2009. Environmental Soil Science. $3^{\text {rd }}$ edition, CRC Press, Taylor and Francis Group, Broken Sound Parkway NW, Boca Raton, FL. pp. .557.

3. Prochnow LI and Cantarella H 2015. Modifying soil to improve crop productivity. Better Crops 99: $10-12$.

4. Rahman MK and Nakamura K 2012. Growth performance of surface and subsurface drip irrigated komatsuna (Brassica campestris L.) grown in soil. Physiol. Ecol. \& Environ. Sci. 3: 43- 45.

5. The Daily Star 2016. Tomatoes bring prosperity to Jamuna char villages, finally. The Daily Star, 22nd Jan. 2016. pp. 7.

6. The Daily Star 2017. Squash farming shows promise. The Daily Star, 15 March 2017. pp.13.

7. Roberts TL and Ryan J 2015. Soil and food security. Better Crops 99: 4-6.

8. Nakamura K, Khondaker NA, Rahman MK and Ozawa K 2005. Is subsurface drip irrigation valuable for crop water use efficiency increases in humid area in the dry season? J. Agric. Meteorol. 60: 403-407. 